\title{
Assesment of the patients presenting with severe anemia to the emergency internal medicine clinic
}

\author{
Seydahmet Akin ${ }^{1}$, Ercan Ergin'2, Sinan Kazan', Nurgul Keskin Tukel ${ }^{3}$, \\ Didem Kilic Aydin', Mustafa Tekce ${ }^{1}$, Mehmet Aliustaoglu ${ }^{1}$ \\ ${ }^{1}$ Department of Internal Medicine, Dr. Lutfi Kirdar Kartal Training and Research Hospital, Istanbul, Turkey; \\ 2Department of Internal Medicine, Savastepe State Hospital, Balıkesir, Turkey; \\ ${ }^{3}$ Department of Internal Medicine, Batman State Hospital, Batman, Turkey
}

\section{ABSTRACT}

OBJECTIVE: Etiological evaluation of the patients who were hospitalized with the diagnosis of severe anemia $(\mathrm{Hb}<7 \mathrm{gr} / \mathrm{dl})$ in the emergency internal medicine clinic between January and July, 2013.

METHODS: In this study, 112 patients who were hospitalized in Dr. Lutfi Kirdar Kartal Education and Research Hospital emergency internal medicine clinic with severe anemia between January and July 2013 were retrospectively analyzed. Patients' initial complaints, underlying causes of their anemia and prognosis of the patients were evaluated.

RESULTS: The etiology of anemia was iron deficiency in 60 (53.6\%), chronic kidney failure in 16 (14.2\%), hematologic malignancies in $12(10.7 \%)$, liver cirrhosis in $12(10.7 \%)$ and other non-malignant hematologic disorders in $4(3.6 \%)$ patients.

CONCLUSION: The most common cause of anemia in patients who apply to emergency internal medicine clinic with severe anemia is iron deficiency. The most common complaints on admission are subjective ones such as weakness, fatigue and lassitude. Chronic disease anemia does not cause severe anemia as much as iron deficiency.

Key words: Anemia, chronic disease, iron deficiency.

Received: June 24, 2014 Accepted: November 11, 2014 Online: December 08, 2014

Correspondence: Seydahmet AKIN. Dr. Lutfi Kirdar Kartal Egitim ve Arastirma Hastanesi, Ic Hastaliklari Klinigi, Cevizli, Kartal, Istanbul, Turkey.

Tel: +90 216 - 4413900 / 1624 e-mail: seydahmeta@hotmail.com

(c) Copyright 2014 by Istanbul Northern Anatolian Association of Public Hospitals - Available online at www.kuzeyklinikleri.com 
A nemia refers to decreased erythrocyte count in circulation or decreased hemoglobin content of the blood. Anemia is a finding rather than a disease. The correct diagnosis in a patient with anemia must include the cause of anemia (ie. iron deficiency anemia, and hemolytic anemia etc.), otherwise only a finding is detected, but not the disease $[1,2]$. Hemoglobin and hematocrit values differ with sex and age and also show diurnal variations. The highest levels are seen in the morning whereas the lowest ones are seen in the evening in the same person. But difference between the highest, and the lowest values is not so wide, it rarely exceeds $1 \mathrm{gr} / \mathrm{dl}$ and most of the time it is less than this. The reason of this daily variation is probably the fluctuations in plasma volume. When evaluating an anemic patient and response to treatment, diurnal variations in hemoglobin levels should be taken into account [3]. Epidemiologic studies point out that frequency of anemia increases with age. According to National Health and Nutritional Examination Survey III, anemia is present in $10 \%$ of Americans that are older than 65 years of age. After age 85 , this ratio can reach $25 \%$ in females and $20 \%$ in males [4]. It is stated that the incidence of anemia is between $8.3-16.3 \%$ in Asian countries $[5,6]$. In a study of Choi et al. among 1254 patients older than 60 years of age in 3 cities, incidence of anemia was found to be $13.6 \%$ [6]. Studies in our country also demonstrate variations in the incidence rates of anemia in different age groups $(31.5,16.9$, and $7.9 \%$ in patients older than 50,60 , and 65 years of age, respectively) $[7,8,9]$. This ratio is $21 \%$ in elderly patients who had consulted to internal medicine outpatient clinic [10]. Frequently encountered causes of anemia include malignancies of prostate, genitourinary, and gastrointestinal systems. In spite of the fact that evidence about the effects of hemoglobin levels on health are rapidly accumulating, it is still controversial if these effects are due to anemia or anemia is just an innocent bystander [11]. Studies have shown that anemia increases mortality in elderly patients by causing cardiovascular and neurological complications [12, 13]. Anemia also increases mortality by adversely effecting physical performance and requiring hospitalization due to motion limitation and falls $[14,15]$. In studies in- vestigating the effect of anemia of any etiology on mortality, it has been shown that mortality rates are significantly higher in anemic patients compared to non- anemic ones during long-term follow- up [12, $13,14,15,16]$. Emergency services are used for the situations that emerge suddenly, with acute onset requiring urgent help from a physician. Due to increased rate of elderly in the population, the number of patients in the emergency services has increased. In our study, we evaluated patients who were hospitalized with severe anemia in emergency internal medicine service from etiologic, symptomatological and prognostic perspectives.

\section{MATERIALS AND METHODS}

A hundred and twelve patients who were hospitalized in emergency internal medicine services for severe anemia $(\mathrm{Hb}<7 \mathrm{~g} \%)$ between January and July 2013 were included in this cross-sectional study. Patients' initial complaints, etiologic factors for anemia and prognosis were evaluated. Patients under 18 years of age were excluded from the study. $\mathrm{Pa}$ tients with evidence of active bleeding (gastrointestinal bleeding, intracranial bleeding, hematuria, etc.) at admission were not included in the study.

\section{RESULTS}

Total of 112 patients ( 52 males, $46.3 \%$ and 60 females, $53.7 \%$ ) were included in the study (Figure 1, Table 1). Mean age of the patients was $62.7 \pm 13.6$ years and mean hemoglobin level was $6.5 \pm 3.63 \mathrm{gr} /$

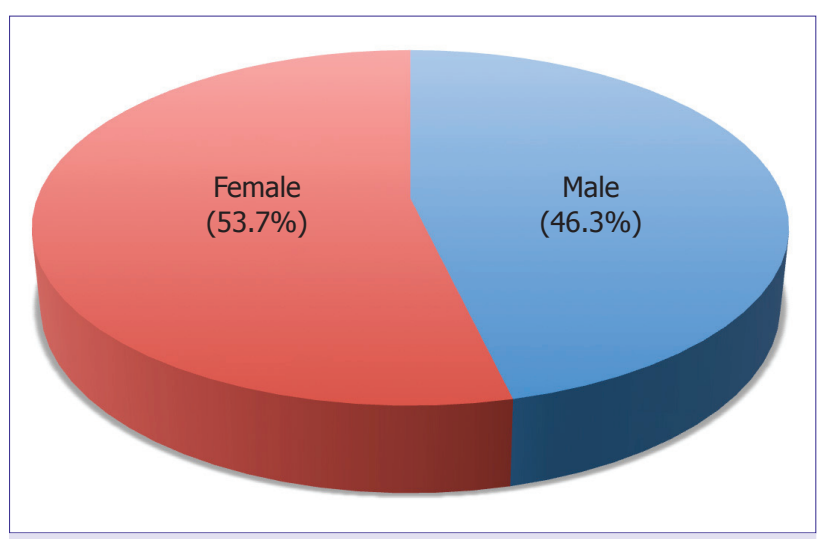

FIGURE 1. Gender distribution. 


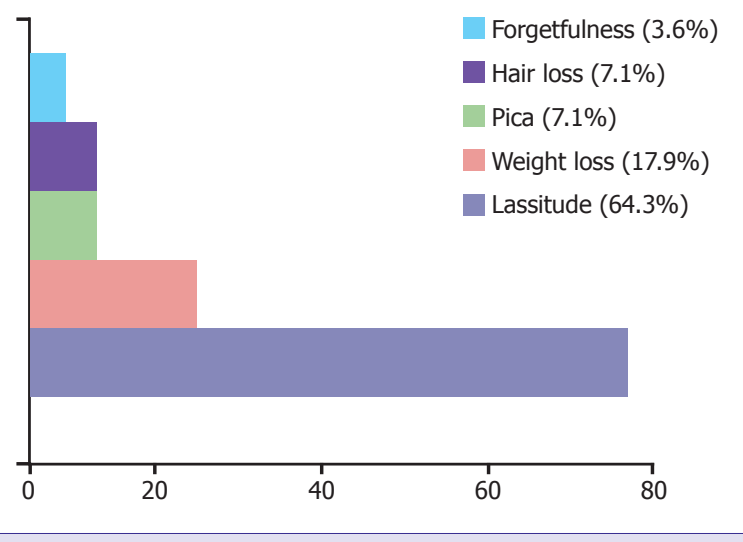

FIGURE2. Complaints in admission.

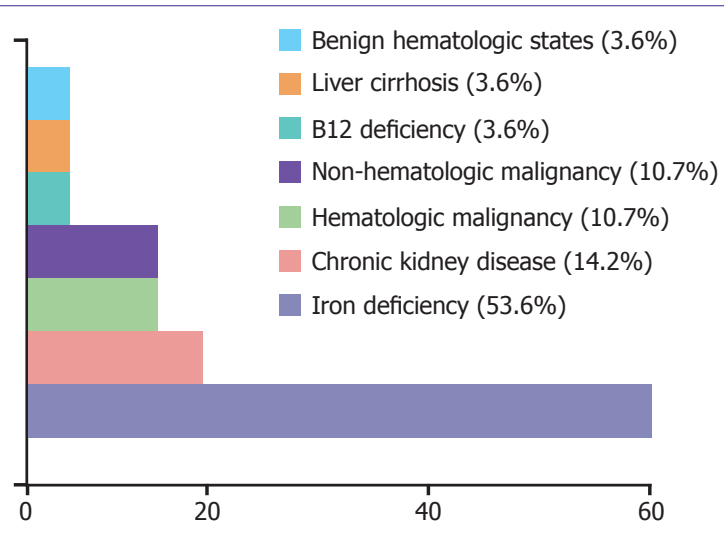

FIGURE 3. Anemia etiology. dl. Patients presented with fatigue, weakness and lassitude ( $n=72 ; 64.3 \%)$, weight loss and night sweats $(n=20 ; 17.9 \%)$ pica signs such as craving for ice and soil, hair loss $(n=8 ; 7.1 \%)$ and amnesia $(n=4$; $3.6 \%$ ) (Figure 2). The etiologies of anemia included iron deficiency in 60 (53.6\%), chronic kidney fail- ure in $16(14.2 \%)$, hematologic malignancies in 12 (10.7\%), hematologic malignancies in 12 (10.7\%), non-hematologic malignancies in $12(10.7 \%)$, liver cirrhosis in 4 (3.6\%), B12 deficiency in 4 (3.6\%) and other non-malignant hematologic disorders in $4(3.6 \%)$ patients (Figure 3, Table 2).

TABLE 1. Gender and age distribution of the patients

Male

$46.3 \%(n=52)$

$60.7 \pm 11.7$
Female

$53.7 \%(n=60)$

$63.9 \pm 12.4$

Mean age of the patients (years)

TABLE2. Some laboratory parametres in various forms of anemia

\begin{tabular}{ccccccc}
$\begin{array}{c}\text { Iron } \\
\text { deficiency }\end{array}$ & $\begin{array}{c}\text { Chronic } \\
\text { kidney } \\
\text { disease }\end{array}$ & $\begin{array}{c}\text { Hematologic } \\
\text { malignancy }\end{array}$ & $\begin{array}{c}\text { Non } \\
\text { hematologic } \\
\text { malignancy }\end{array}$ & $\begin{array}{c}\text { Vit. B12 } \\
\text { deficiency }\end{array}$ & $\begin{array}{c}\text { Liver } \\
\text { cirrhosis }\end{array}$ & $\begin{array}{c}\text { Benign } \\
\text { hematologic } \\
\text { disease states }\end{array}$ \\
6.2 & 6.9 & 6.4 & 6.1 & 6.8 & 6.4 & 6.9 \\
59 & 62 & 101 & 74 & 112 & 82 & 88 \\
7480 & 9200 & 3200 & 2100 & 3500 & 4590 & 6500 \\
225000 & 185000 & 64000 & 74000 & 56000 & 110000 & 35000 \\
5.3 & 7.4 & 125 & 95 & 105 & 135 & 124 \\
350 & 240 & 900 & 1010 & 35 & 395 & 712 \\
8.2 & 6.5 & 14 & 8 & 5 & 6 & 12 \\
\hline
\end{tabular}

$\mathrm{HB}(\mathrm{gr} / \mathrm{dL})$

MCV (fl)

WBC $\left(/ \mathrm{mm}^{3}\right)$

PLT $\left(/ \mathrm{mm}^{3}\right)$

FERRITIN $(\mathrm{ng} / \mathrm{mL})$

Vit. B12 (pg/mL)

Folate $(\mathrm{ng} / \mathrm{mL})$

Hb: Hemoglobin; MCV: Mean corpuscular volume; WBC: White blood cell counts; PLT: Platelets. 


\section{DISCUSSION}

Most patients apply to physicians with known symptoms of anemia. But sometimes prominent symptoms are related to disease that anemia stem from. It is not rare that patients see doctors with different complaints and coincidentally iron deficiency is found. Although weakness, fatigue, lassitude, palpitation, headache, dyspnea and pallor are mostly seen reasons for seeing a doctor, they are nonspecific and can be seen in pathologies other than anemia. In our study, weakness, fatigue and lassitude were mostly seen complaints with a frequency of $64.3 \%$. In 20 patients $(17.9 \%)$ night sweats and weight loss were more prominent. Pica syndrome which is seen in iron, cupper or zinc deficiency was present in only $8(7.1 \%)$ patients. In a study of Young et al., pica syndrome was found to be strongly related to iron deficiency and seen in $40 \%$ of the patients with iron deficiency [17]. Accordingly, it could be expected to see more pica syndrome patients among iron deficient patients in our study. Pica syndrome which is defined as consumption of uneatable objects is not one of the reasons for emergency service visit. That is why its incidence may seem lower than expected. It is thought that a research with patients from internal medicine outpatient clinics will yield results comparable to those reported in the literature. In a study by Joosten et al., etiologic factors for anemia in elderly population were as follows: chronic disease anemia (34\%), iron deficiency anemia (15\%), vitamin B12 and folate deficiency anemia (5.6\%), idiopathic anemia (17\%), post hemorrhagic anemia (7.3\%), chronic leukemia or lymphoma (5.1\%) and myelodysplastic syndrome and acute leukemia $(5.6 \%)$ [18]. In our study, iron deficiency was the leading cause of anemia in 60 patients $(53.6 \%)$. The other detected etiologies were chronic kidney failure (14.2\%), hematologic malignancies (10.7\%), liver cirrhosis $(10.7 \%)$ and nonmalignant hematologic pathologies (3.6\%). The reason of this difference is probably due to the fact that we only included patients with hemoglobin levels under $7 \mathrm{gr} / \mathrm{dl}$ in our study. Anemia is not severe in chronic disease anemia as reported by various studies in the literature. But in a study of Chernetsky et al., the leading cause of anemia was chronic diseases (65\%), followed by chronic liver disease (13.2\%), nutritional deficiency (iron, vitamin B12, folate) (4\%) and idiopathic etiologies (15.9\%) [19]. As a similar result, chronic kidney failure was found to be the second leading cause of anemia with a rate of $14.2 \%$ in our study. A significant correlation between anemia and nutritional deficiency has been also revealed [20, 21]. Iron deficiency anemia is characterized by decreased iron storage, low serum iron transferrin saturation, hemoglobin and hematocrit levels. Iron deficiency may develop because of several different factors such as low iron intake from diet, malabsorption, chronic blood loss, usage for erythropoiesis in fetus or by lactating, hemoglobinuria with intravascular hemolysis or combinations of these factors [22]. It is caused by uncompensated iron needs in increased demand or pathologic conditions that effects iron balance negatively. Choi et al. reported that increased age, decreased albumin, increased creatinine and decreased body mass index are independent risk factors for anemia in elderly population [23]. In our study, the most common etiologic factor in patients hospitalized with severe anemia was found to be iron deficiency anemia. As seen in the literature, in our study, nutritional deficiency of iron plays the main role in iron deficiency. But results of our study were found to be different than most sources in the literature. The main reason of this difference is thought to be that only patients with severe anemia were included in our study. Etiologic factors vary between anemia in outpatient clinic patients and severe anemia that requires blood transfusion. In fact, chronic disease anemia which is seen frequently in normal population rarely causes severe anemia. This study only shows the frequency of severe anemia in emergency internal medicine service and does not reflect the actual rate in population. Moreover, because the study is cross- sectional, it provides limited information about anemia patients. But despite this limitation, this study has a critical importance in that it shows frequent symptoms and reasons of severe anemia in patients that are hospitalized in an emergency internal medicine service, and emphasizes that further examination may be needed in severe anemia patients. Furthermore, larger studies about 
anemia prevalence and incidence should be done not only in patients visiting outpatient clinics with mild complaints, but also in asymptomatic patients in general population.

Conflict of Interest: No conflict of interest was declared by the authors.

Financial Disclosure: The authors declared that this study has received no financial support.

\section{REFERENCES}

1. Lux SE. Introduction to anemias. In: Handin RI, Lux SE, Stossel TP, editors. Blood principles \& Practice of Hematology. Philadelphia: Lippincott Co; 1995. p. 1383-98.

2. Atamer T. Anemik hastaya yaklaşım. Büyük öztürk K (ed). İç hastalıkları. Nobel Tip Kitabevleri: İstanbul; 1992. p. 427-34.

3. Bessman JD, Johnson RK. Erythrocyte volume distribution in normal and abnormal subjects. Blood 1975;46:369-79.

4. Gunter EW, Lewis BG, Koncikowski SM. Laboratory procedures used fort he third national health and nutrition examination survey (NHANES III) 1988-1994. Atlanta: GA 30341-3724; National Centers of Disease Control and Prevention: 1996.

5. Bang SM, Lee JO, Kim YJ, Lee KW, Lim S, Kim JH, et al. Anemia and activities of daily living in the Korean urban elderly population: results from the Korean Longitudinal Study on Health and Aging (KLoSHA). Ann Hematol 2013;92:59-65. CrossRef

6. Choi CW, Lee J, Park KH, Yoon SY, Choi IK, Oh SC, et al. Prevalence and characteristics of anemia in the elderly: crosssectional study of three urban Korean population samples. Am J Hematol 2004;77:26-30. CrossRef

7. Özdemir L, Koçoglu G, Sümer H, Nur N, Polat H, Aker A, ve ark. Sivas ili merkezinde yaşlı nüfusta bazı kronik hastalıkların prevalansı ve risk faktörleri. CÜ Tip Fakültesi Dergisi 2005;27:89-94.

8. Kisioglu AN, Uskun E, Ozturk M. Socio-demographical examinations on disability prevalence and rehabilitation status in southwest of Turkey. Disabil Rehabil 2003;25:1381-5. CrossRef

9. Çetin İ, Bulut Y, Yıldırım B, Ozturk B, Yenisehirli G, Etikan I, Ozdemır M, et al. The investigation of some hematological values and anemia prevalence in adult population of Tokat province. International Journal of Hematology and Oncology 2009;19:166-74.
10. Çelebi H, Vardı Ş, Tahtacı M, Tamer A, Balaban Y, Kanat M, ve ark. İzzet Baysal Tip Fakültesi İç Hastalıkları polikliniğine başvuran 50 yaş üstü bireylerde kronik hastalık sıklığı. AİBÜ İzzet Baysal Tip Dergisi 2009;4:38-42.

11. Nissenson AR, Goodnough LT, Dubois RW. Anemia: not just an innocent bystander? Arch Intern Med 2003;163:1400-4.

12. Izaks GJ, Westendorp RG, Knook DL. The definition of anemia in older persons. JAMA 1999;281:1714-7. CrossRef

13. Denny SD, Kuchibhatla MN, Cohen HJ. Impact of anemia on mortality, cognition, and function in community-dwelling elderly. Am J Med 2006;119:327-34. CrossRef

14. Penninx BW, Pahor M, Cesari M, Corsi AM, Woodman RC, Bandinelli S, et al. Anemia is associated with disability and decreased physical performance and muscle strength in the elderly. J Am Geriatr Soc 2004;52:719-24. CrossRef

15. Chaves PH, Ashar B, Guralnik JM, Fried LP. Looking at the relationship between hemoglobin concentration and prevalent mobility difficulty in older women. Should the criteria currently used to define anemia in older people be reevaluated? J Am Geriatr Soc 2002;50:1257-64. CrossRef

16. Chalmers KA, Knuiman MW, Divitini ML, Bruce DG, Olynyk JK, Milward EA. Long-term mortality risks associated with mild anaemia in older persons: the Busselton Health Study. Age Ageing 2012;41:759-64. CrossRef

17. Young SL, Khalfan SS, Farag TH, Kavle JA, Ali SM, Hajji H, et al. Association of pica with anemia and gastrointestinal distress among pregnant women in Zanzibar, Tanzania. Am J Trop Med Hyg 2010;83:144-51. CrossRef

18. Joosten E, Pelemans W, Hiele M, Noyen J, Verhaeghe R, Boogaerts MA. Prevalence and causes of anaemia in a geriatric hospitalized population. Gerontology 1992;38:111-7. CrossRef

19. Chernetsky A, Sofer O, Rafael C, Ben-Israel J. Prevalence and etiology of anemia in an institutionalized geriatric population. [Article in Hebrew] Harefuah 2002;141:591-4, 667. [Abstract]

20. Smith DL. Anemia in the elderly. Am Fam Physician 2000;62:1565-72.

21. Woodman R, Ferrucci L, Guralnik J. Anemia in older adults. Curr Opin Hematol 2005;12:123-8.

22. Foirbanks VF, Beutler E. Iron Defiency. In: Ernest Beutler, editor. Williams Hematology 5th edition. Mc Grow-Hill: USA; 1995. p. 490-506.

23. Choi CW, Lee J, Park KH, Yoon SY, Choi IK, Oh SC, et al. Prevalence and characteristics of anemia in the elderly: crosssectional study of three urban Korean population samples. Am J Hematol 2004;77:26-30. CrossRef 